\title{
The effect of the substratum on the in vitro culture of Cymbidium
}

\author{
KRYSTYNA KUKULCZANKA *, BARBARA CZASTKA *, \\ ANNA MARCZONEK ** \\ * Wrocław University Botanical Garden, ul. Sienkiewicza 23, \\ Wrocław, Poland \\ ** Institute of Botany, Wrocław University, ul. Kanonia 6/8 \\ Wrocław, Poland
}

(Feceived: July 8, 1986)

\begin{abstract}
The effect of different substrata (agar, pearl barley, oat flakes and perlite) on the growth and development of orchids. Cymbidium, in the early stages of development in in vitro cultures was studied. Liquid PB medium, complete and without peptone, was added to the substratum. The best growth of Cymbidium shoots and roots was observed on pearl barley. The oat flake substratum favored the growth of shoots, however, due to poor air proportions, the numerous developing roots were damaged. The few roots which arose on the traditional agar substratum grew on its surface. Perlite provided perfect air conditions for the development of roots, but was too poor in nutrients. The presence of peptone in the medium caused the increase of fresh weight of Cymbidium plants. The macroelement content in the plant was dependent on the supply from the substratum used.
\end{abstract}

\section{INTRODUCTION}

The growth and development of orchids in the early stages of in vitro culture depend not only on the composition of the medium, but also on the properties of the substratum used. Orchid tissues grow very well in liquid medium, but in order to ensure the proper development of plants from the newly formed protocorms, they should be placed on a solidified substratum (K u k u $\mathrm{cz}$ a n k and $\mathrm{P} \mathrm{a} \mathrm{l} \mathrm{u} \mathrm{c} \mathrm{h,} \mathrm{1971;} \mathrm{K} \mathrm{u} \mathrm{k} \mathrm{u} \mathrm{l-}$ $\mathrm{czanka}, 1976$ ). Medium gelled with agar is most commonly employed. This substratum is uniformly solid. The orchid roots being formed usually do not penetrate into such a substratum, but grow out over its surface. One of the drawbacks of media and substrata, used in the several month long culture of orchids is their increasing acidification due to the 
uptake of cations and respiration by tissues. The $\mathrm{pH}$ initially set at over 5 , drops during culture to values even below $\mathrm{pH} 3$ ( $\mathrm{Kukurczanka}$ and $\mathrm{S}$ arosiek, 1971).

Many authors suggest enriching mineral media with nutrient and phytohormone complexes, especialy coconut milk and banana pulp, in order to ensure the better growth of seedlings and young plants ( $M$ or e 1, 1974 ; $\mathrm{R}$ a o, 1977). These complexes do not have a known, uniform composition and, in addition, are hard to come by in this country.

In vitro culture of orchids carried out for many years and the observations made during that time have given us reason to try substrata other than agar-agar for the culture of orchids ( $\mathrm{Kukulczanka}$, 1976). In order to improve the air-water conditions for the growth of the roots of orchid plantlets developing from protocorms obtained through the subculture of meristematic tissue, the suitability of other organic and inorganic products for this culture was examined. Grain products, rich in starch, protein, polypeptides and vitamins from the bios group, seemed appropriate for this purpose. Perlite, commonly used in the rooting of decorative plant seedlings and in in vitro cultures (Aldrufeu, 1985), was chosen as the inorganic substratum.

\section{MATERIAL AND METHODS}

Studied was the meristematic tissue of two varieties of Cymbidium, namely, C. vallambrosa and C. Vieux Rose del Park. After 4 weeks of subculture on a liquid medium, young tissue was transferred to the studied substratum. The $\mathrm{PB}$ medium according to Tsuchiya modified according to Kukułczanka (Kukułczanka and $\mathrm{Paluch}, 1971$; $\mathrm{Kuku} ¥ \mathrm{czanka}, 1976)$ was used. The full medium with and without peptone was employed. The starting $\mathrm{pH}$ of the medium was 5.6. Flasks containing the medium and substratum were sterilized in an autoclave at 1 atmosphere and temperature of $117^{\circ} \mathrm{C}$.

The following products were used to gel the substrata:

1. Agar-agar (Kobo, Japan, $8 \mathrm{~g} / 1$ ) $480 \mathrm{mg}$ and $60 \mathrm{ml}$ liquid medium in a $200 \mathrm{ml}$ Erlenmayer flask,

2. pearl barley $-10 \mathrm{ml}(9.5 \mathrm{~g})$ and $60 \mathrm{ml}$ PB per flask,

3. oat flakes - $20 \mathrm{ml}(7.6 \mathrm{~g})$ and $60 \mathrm{ml} \mathrm{PB}$ per flask,

4. perlite $-50 \mathrm{ml}$ and $35 \mathrm{ml} \mathrm{PB}$ per flask.

As was shown by chemical analysis, the agar and perlite substrata contained trace amounts of macroelements, whereas pearl barley and oat flakes were rich in nitrogen, phosphorous and potassium (Table 1).

The experiment was started on March 20, 1985 in 8 combinations. Each substratum was enriched with PB medium with or without peptone (peptobak-Bacutil). Each combination was tested in 4 Erlenmayer 
T a ble 1

Contents of macroelements (in per cent) in the applied substrata

\begin{tabular}{lccccc}
\hline \multicolumn{1}{c}{ Substrata } & $\mathrm{N}$ & $\mathrm{P}$ & $\mathrm{K}$ & $\mathrm{Ca}$ & $\mathrm{Mg}$ \\
\hline Agar & 0.08 & 0.01 & 0.06 & 0.12 & 0.11 \\
Pearl barley & 1.56 & 0.31 & 0.34 & 0.08 & 0.16 \\
Oat flakes & 2.11 & 0.45 & 0.37 & 0.10 & 0.24 \\
Perlite & 0.05 & 0.01 & 0.04 & 0.11 & 0.06 \\
\hline
\end{tabular}

flasks. Five pieces of tissue about $5 \mathrm{~mm}$ in diameter from a given Cymbidium variety were inoculated in to each flask.

The cultures were placed in a culture rcom in daylight supplemented with fluorescent lighits, in photoperiods extended to $16 \mathrm{~h}$ and a temperatures of $20-26^{\circ} \mathrm{C}$. The light intensity ranged from 2000 to $7000 \mathrm{~lx}$.

Observations on the growth and develcpment of the plants were recorded daily. After 4 months (August 4, 1985) the plants were removed from the flasks and their size and rooting were examined. Due to the high interobjective variability, variance analysis was not applied to the results but only mean and extreme values were calculated.

Next, chemical analysis of the plant along with the tissue and remaining post-culture substratum was carried out. The material was dried at $65^{\circ} \mathrm{C}$, then incinerated in a muffle furnace at $450^{\circ} \mathrm{C}$, the ash dissolved in $20 \% \mathrm{HCl}$. Phosphorous was assayed by the molybdate method ( $\mathrm{B} \mathrm{a} \mathrm{b-}$ $\mathrm{ko}$ and $\mathrm{Pilipienko}$, 1955). Potassium was determined in a flame photometer using a modified method of Johnson-Urlich (Now o s i e lski, 1968). Calcium and magnesium were assayed by the Barrous and Simpson (1962) EDTA method. For the determination of nitrogen, the plants and substrata were mineralized in concentrated sulfuric acid (Mejbaum-Katzenellenbogen and Mochnacka, 1968).

\section{RESULTS}

Cymbidium plants developed from protocorms on all of the tested media. However, the plants developing on the agar substratum with the $\mathrm{PB}$ medium without peptone and those on perlite were light green, and the developing protocorms yellowish. The protocorms and plants on the remaining media were intensely green.

It was found that the C. vallambrosa plants were more advanced in their development than C. Vieux Rose del Park plants, which is related to the natural earliness of the former variety (Table 2). The growth and development of plants from both Cymbidium varieties proceeded differently, depending on the substratum used. The number of 
Table 2

The influence of substratum on the srowth and the development of Cymbidium plantlets cultured in vitro

\begin{tabular}{|c|c|c|c|c|c|c|c|c|c|c|c|c|}
\hline & & & Protocorms & Leaves & & Shoots & & & Roots & & & \\
\hline & tum & & No. & No. & $\begin{array}{l}\max \\
\mathrm{cm}\end{array}$ & $\begin{array}{l}\text { length } \\
\text { mean } \\
\mathrm{cm}\end{array}$ & No. & $\begin{array}{c}\max \\
\mathrm{cm}\end{array}$ & $\begin{array}{c}\text { length } \\
\text { mean } \\
\mathrm{cm}\end{array}$ & No. & $\begin{array}{l}\text { Rooting } \\
\text { coefficient }\end{array}$ & $\begin{array}{c}\text { weight } \\
\mathrm{g} \\
\end{array}$ \\
\hline & & & & & & dium $v a$ & brosa & & & & & \\
\hline Agar & + & peptone & 257 & $3-4$ & 9.0 & 4.0 & 88.3 & 3.0 & 0.5 & 92.0 & 1.04 & 11.1 \\
\hline Agar & & - & 225 & $2-4$ & 6.0 & 2.5 & 56.5 & 6.0 & 1.5 & 73.3 & 1.30 & 7.9 \\
\hline Pearl barley & + & peptone & 249 & $3-6$ & 17.0 & 7.0 & 90.8 & 7.0 & 4.0 & 140.0 & 1.92 & 21.1 \\
\hline Pearl barley & & - & 218 & $3-5$ & 13.0 & 7.0 & 85.8 & 7.0 & 3.5 & 165.3 & 1.96 & 17.7 \\
\hline Oat llakes & + & peptone & 252 & $2--5$ & 15.0 & 8.0 & 102.5 & 3.5 & 1,5 & 166.3 & 1.52 & 19.5 \\
\hline Oat flakes & & - & 285 & $2-5$ & 16.0 & 8.0 & 103.2 & 4.0 & 1.5 & 154.5 & 1.50 & 17.6 \\
\hline Perlite & + & peptone & 112 & $2-5$ & 8.0 & 4.0 & 40.3 & 7.0 & 3.0 & 104.5 & 2.59 & 7.1 \\
\hline Perlite & & - & 101 & $2-5$ & 8.0 & 4.0 & 38.3 & 11.0 & 3.5 & 69.5 & 1.81 & 7.3 \\
\hline & & & & & Cymbid & Venx $I$ & del Par & & & & & \\
\hline Agar & + & peptone & 444 & $0-5$ & 10.0 & 1.0 & 107.0 & 8.0 & 0.8 & 17.8 & 0.17 & 15.4 \\
\hline Agar & & - & 287 & $0-3$ & 5.5 & 0.4 & 30.3 & 7.0 & 0.4 & 9.5 & 0.31 & 8.7 \\
\hline Pearl barley & + & peptone & 229 & $1-5$ & 11.0 & 3.0 & 73.8 & 5.0 & 2.0 & 38.8 & 0.53 & 16.9 \\
\hline Pearl barley & & - & 203 & $1-5$ & 10.0 & 4.0 & 58.8 & 7.0 & 2.8 & 38.0 & 0.65 & 8.3 \\
\hline Oat flakes & + & peptone & 279 & $1-4$ & 14.5 & 5.0 & 98.3 & 4.0 & 1.5 & 50.0 & 0.51 & 14.6 \\
\hline Oat flakes & & - & 184 & $1-4$ & 10.0 & 3.5 & 58.3 & 4.5 & 2.0 & 41.0 & 0.70 & 8.4 \\
\hline Perlite & + & peptone & 396 & $1-3$ & 8.0 & 1.5 & 88.5 & 4.0 & 1.0 & 14.8 & 0.17 & 8.1 \\
\hline Perlite & & - & 333 & $1-3$ & 6.0 & 1.2 & 43.8 & 4.0 & 1.5 & 14.8 & 0.34 & 7.0 \\
\hline
\end{tabular}


protocorms in all of the combinations increased. An especially large number of protocorms was observed in the more slowly developing C. Vieux Rose del Park plants growing on agar and perlite substrata. C. vallambrosa tissue on perlite developed the smallest number of protocorms.
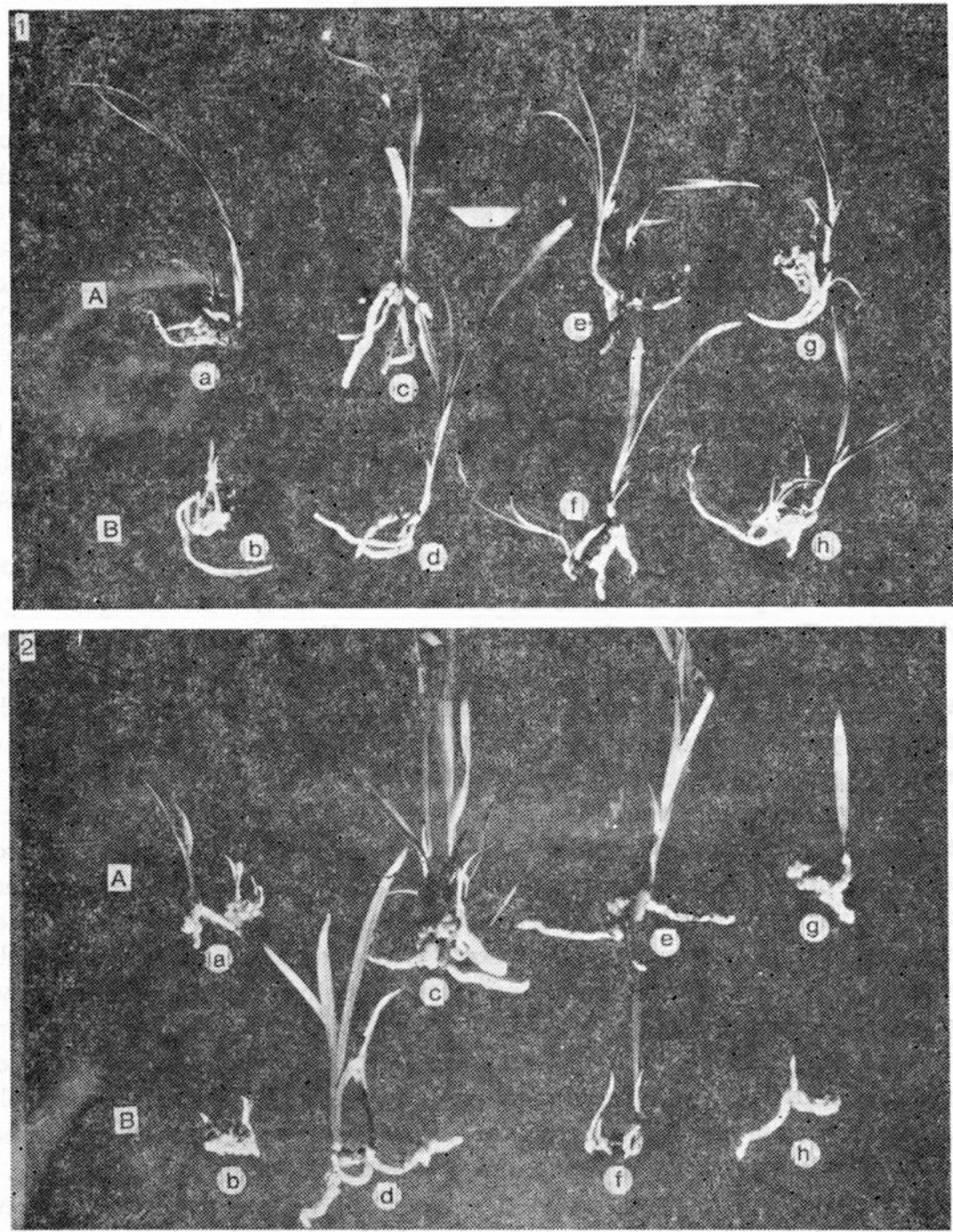

Fig. 1-2. Cymbidium vallambrosa (Fig. 1) and Cymbidium Vieux Rose del Parlc (Fig. 2) plants after 4 months of in vitro culture on experimental substrata. A PB medium with peptone, B - PB medium without peptone. Substrata: agar (a, b); pearl bariey (c. d); oat flakes (e, f); perlite $(g, h)$ 
Plants of the same variety did not significantly differ in their number of leaves. The longest stems were formed by plants on pearl barley and oak flake substrata (Table 2, Figs. 1,2). The number of shoots formed by $C$. vallambrosa on these substrata was also distinctly higher than on agar or perlite. In C. Vieux Rose del Park, however, the presence of peptone in the medium influenced the formation of a greater number of shoots.

The longest and healthiest roots were formed by the plants on the pearl barley and perlite substrata (Table 2, Figs. 1, 2). Single, long roots were also observed in C. Vieux Rose del Park plants growing on the agar medium, whereas the plants growing on agar and oat flakes had dark, damaged root apices. These roots, in contact with the substratum inhibited growth. Plants from both varieties formed the most roots on oat flakes and pearl barley. The ratio of the number of roots to the number of shoots, in other words, the rooting coefficient, was the highest in plants growing on pearl barley and flakes and in the case of C. vallambrosa, also on perlite. The varieties differed in the value of their rooting coefficients. The early $C$. vallambrosa variety had a higher coefficient than C. Vieux Rose del Park, which is related to their different degree of development.

Cymbidium vallambrosa plants growing on pearl barley and oat flake substrata produced twice as much fresh weight as those on agar and perlite. The presence of peptone in the medium increased the amount of fresh weight, which was especially evident in C. Vieux Rose del Park (twice as much). The presence of peptone in the medium in the case of the agar and perlite substrata also influenced the formation of a higher number of protocorms and shoots (Table 2).

The content of macroelements $(\mathrm{N}, \mathrm{P}, \mathrm{K})$ in the employed substratum (Table 1) was mirrored in the level of these elements in the analysed plants and in their level in the substrata at the end of the experiment (Table 3). A positive correlation between the content of the studied elements in the substrata and in plants was especially distinct when the medium without peptone was added to the substratum. The plants growing on the agar and perlite substrata with mediums lacking peptone contained less nitrogen, phosphorous and potassium than the plants on the same substrata with peptone-enriched medium. The plants on the pearl barley and oat flake substrata contained more nitrogen, phosphorous and potassium than the plants on the perlite and agar substrata.

Analysis of the content of elements in the substrata at the conclusion of the experiment revealed the correlation between the composition of the medium and the uptake of its components by the plants. In perlite, all of the elements were almost completely take up. Potassium was almost entirely used up from the agar substratum, as was nitrogen in the 
Table 3

Contents of macroelements (in per cent) in Cymbidium plantlets and in the substratum at the end of the experiment

\begin{tabular}{|c|c|c|c|c|c|c|c|c|c|}
\hline \multirow{2}{*}{\multicolumn{3}{|c|}{ Substrata }} & \multicolumn{3}{|c|}{ Plantlets } & \multicolumn{4}{|c|}{ Substrata } \\
\hline & & & $\mathbf{N}$ & $\mathrm{P}$ & $\mathrm{K}$ & $\mathbf{N}$ & $\mathbf{P}$ & $\mathrm{K}$ & $\mathrm{pH}$ \\
\hline \multicolumn{10}{|c|}{ Cymbidium vallambrosa } \\
\hline$\overline{\text { Agar }}$ & & peptone & 3.00 & 0.77 & 1.07 & 0.50 & 0.19 & 0.02 & 3.40 \\
\hline Agar & & - & 2.03 & 0.62 & 0.99 & 0.17 & 0.21 & 0.08 & 3.50 \\
\hline Pearl barley & & peptone & 2.53 & 0.77 & 1.03 & 1.48 & 0.23 & 0.06 & 3.60 \\
\hline Pearl barley & + & - & 2.30 & 0.79 & 1.14 & 1.39 & 0.21 & 0.04 & 3.95 \\
\hline Oat flakes & & peptone & 3.10 & 0.92 & 1.39 & 1.93 & 0.27 & 0.08 & 4.24 \\
\hline Oat flakes & & - & 2.55 & 0.82 & 1.29 & 1.98 & 0.34 & 0.09 & 4.40 \\
\hline Perlite & & peptone & 3.28 & 0.66 & 1.29 & 0.12 & 0.04 & 0.03 & 4.05 \\
\hline Perlite & & - & 1.96 & 0.55 & 1.08 & 0.06 & 0.02 & 0.03 & 4.10 \\
\hline
\end{tabular}

Cymbidium Vieux Rose del Park

\begin{tabular}{|c|c|c|c|c|c|c|c|c|c|}
\hline Agar & + & peptone & 2.76 & 0.73 & 1.07 & 0.53 & 0.19 & 0.01 & 3.60 \\
\hline Agar & & - & 1.65 & 0.55 & 0.97 & 0.15 & 0.22 & 0.03 & 3.43 \\
\hline Pearl barley & + & peptone & 2.67 & 0.75 & 1.26 & 1.52 & 0.30 & 0.18 & 3.77 \\
\hline Pearl barley & & - & 2.50 & 0.75 & 1.28 & 1.40 & 0.31 & 0.19 & 4.10 \\
\hline Oat flakes & + & peptone & 2.68 & 0.82 & 1.32 & 2.03 & 0.40 & 0.13 & 4.30 \\
\hline Oat flakes & & - & 2.54 & 0.82 & 1.26 & 1.96 & 0.42 & 0.19 & 4.40 \\
\hline Perlite & + & peptone & 3.08 & 0.65 & 0.98 & 0.09 & 0.04 & 0.03 & 4.24 \\
\hline Perlite & & - & 1.74 & 0.55 & 0.94 & 0.05 & 0.02 & 0.03 & 4.20 \\
\hline
\end{tabular}

combination without peptone. Potassium was clearly taken up to a high degree in the pearl barley and oak flake substrata, this was the most noticable in the substratum left after $C$. vallambrosa, which is more advanced in its development. Excess nitrogen and phosphorous remained in these substrata. The analysis of the calcium and magnesium contents showed that the media had not been completely exhausted of them. The highest amount of magnesium remained in the oat flakes.

The substrata differed in their $\mathrm{pH}$. The agar and pearl barley substrata were the most acidified $(\mathrm{pH} 3.4-4.1)$. The perlite substratum was not so acidic ( $\mathrm{pH} 4.05-4.24$ ), and the least acidic was the oat flake substratum ( $\mathrm{pH}$ 4.24-4.40) (Table 3).

At the end of the experiment, the perlite substratum was considerably dried out and loose. Pearl barley remained lumpy and reasonably moist. The agar substratum was hard and solid, whereas the oat flake substratum was clearly moist and sludgy. 


\section{DISCUSSION}

The results obtained in this study show that it is possible to replace agar with other substrata in the in vitro culture of orchids in early developmental stages. Pearl barley and oat flakes clearly stimulated the growth of Cymbidium shoots. Especially C. vallambrosa plants greatly increased their weight on these substrata in comparison with plants from the agar and perlite substrata. Chemical analysis also showed slight increases in the nitrogen, phosphorous and potassium contents in these plants.

Obtaining plants with strong and healthy root systems is of particular importance in the in vitro culture of plants. An abundant and healthy root system is decisive in the adaptation of the plant to pot culture after transplantation from in vitro culture. The Cymbidium plants from the pearl barley and perlite substrata had perfect and healthy root systems. It can be accepted that the physical properties of the substrata were decisive in this. Pearl barley and perlite retained their lumpy structure with clearly visible air pockets. The roots of Cymbidium plants growing on agar grew on its surface, therefore the uptake of nutrients from the medium was lower. The behaviour of plants on the moist, sludgy oat flake medium was interesting. These plants formed numerous roots which ceased to grow when they came in contact with the substratum and their apices turned dark. Cymbidium roots on agar also underwent similar damage, but to a lesser extent. It can be assumed that the air-water relationship in the substratum had a decisive role in the behaviour of the roots of the studied plants, and that the substratum acidity had a smaller influence. Improving the air-water relationship in the oat flake substratum would probably prevent damage to the roots. As was shown (Table 3) pearl barley and agar were characterized by the lowest $\mathrm{pH}(3.40-4.10)$, and oat flakes and perlite maintained a $\mathrm{pH}$ over 4 (4.05-4.40), which did not correlate with the growth of Cymbidium roots.

As has previously been shown, peptobak-Bacutil in PB medium stimulates the growth of tissues and protocorms as well as the development of various orchids ( $\mathrm{Kukulczanka}$ and $\mathrm{Paluch}, 1971 ; \mathrm{Ku}-$ $\mathrm{kułczanka}$ et al., 1975; Kukułczanka, 1976; Kukułczanka and Wojciechowska, 1983; Kukulczanka and Kromer, 1984). The stimulation of the development of plants due to peptone in the medium was very evident in all of the substrata used with $C$. Vieux Rose del Park, whereas with C. vallambrosa, it was visible mainly on the substrata poor in nutrients, namely perlite and agar. The morphologic and morphogenic observations on the development of plants of different substrata were confirmed by the analysis of the level of nutrients in the studied plants. 
Perlite, which is successfully used in the rooting of decorative plants, has already been used in the in vitro culture of Pelargonium (A l d r u$\mathrm{fe} u, 1985$ ). In this study, perlite was inferior to the pearl barley substratum. It should however be remembered that only $35 \mathrm{ml}$ of the liquid medium were added to the flasks with perlite. The low specific gravity and looseness of perlite technically did not allow greater amounts of the medium to be used. The quantitative supplementation of the medium would probably improve the effects. After a few weeks of culture, the remaining portion of the medium should have been added to the flasks. The good growth of Cymbidium shoots and the initiation of large numbers of roots on the pearl barley and oak flake substrata also can be related to the stimulating effects of growth regulators from the bios group. Oak flakes are sometimes used as the substratum for fungi cultures ( $\mathrm{Johnson}$ and Cur 1, 1972), as is an extract from barley sprouts used as a growth stimulating complex for in vitro tissue cultures (G a u theret, 1959).

\section{CONCLUSIONS}

1. The traditional agar substratum with the appropriate nutrient medium ensures Cymbidium good edaphic conditions for the development of plants, however, its consistency, and poor air conditions do not favor the penetration of roots into the substratum.

2. Pearl barley enriches the medium additionally with macro-and microelements. It favors the growth of Cymbidium roots and shoots and is a better substratum than agar, oat flakes or perlite. It could therefore be used instead of agar in laboratories producing orchids.

3. Oat flakes are a substratum very rich in macro- and microelements. They effect the strong growth of Cymbidium shoots and the formation of numerous roots. However, due to poor air conditions, this substratum inhibits the growth of roots.

4. Perlite is a substratum very poor in nutrients and hard to enrich. Nevertheless, it creates perfect air conditions for the development of Cymbidium roots.

5. The presence of peptone in the PB medium causes an increase in the fresh weight of plants; depending on the Cymbidium variety, even by up to two-fold.

\section{REFERENCES}

A larufeu A., 1985. Rooting and acclimatation of Pelargonium zonale plantlets. Symposium "In vitro problems related to masspropagation of Horticultural plants" Gemblaux, Book of Abstracts p. 50. 
Babko A. K., Pilipienko A., 1955. Analiza kolorymetryczna. PWT, Warszawa. Barrous H. L., Simpson B. C., 1962. An EDTA method for direct routine determination of calcium and magnesium in soils and plant tissue. Soil Sci. Soc. Amer. Proc. 26: 443-445.

Ga utheret R. J., 1959. La culture des tissus vegetaux. Masson Edi. Paris.

Johnson L. F., Curl E. A., 1972. Methods of research on the ecology of soil-borne plant pathogens. Burges Publ. Minneapolis p. 189.

Kukułczanka K., 1976. Einfluss von Phytohormonen auf das Wachstum von Meristemgewebe und frühe Entwicklungsphasen von Cymbidium. Proc. 8th World Orchid Conference, Frankiurt 1975. pp. 384-389.

Kukułczanka K., Kromer K., 1984. Namnażanie i rozwój protokormów Phalaenopsis w kulturach in vitro. Acta Universitatis Wratislaviensis 667/30: 15-29.

Kukułczanka K., Paluch B., 1971. Zastosowanie peptonu Peptobak-Bacutil w hodowli merystematycznej tkanki Cymbidium Sw. Acta Agrobot. 24: 53-62.

Kukułczanka K., Pa lu ch B., Wożakowska-Natkani ec H., 1975. Wpływ hydrolizatu kazeiny na wzrost tkanki merystematycznej storczyka Cymbidium w kulturze in vitro. Prace Instytutu Sadownictwa Seria B1: 63-70.

Kukułczanka K., Sarosiek J., 1971. Merystematyczne kultury storczyków. Wiad. Bot. 15: 29-40.

Kukułczanka K., Wojciechowska U., 1983. Propagation of two Dendrobium species by in vitro culture. Acta Hortic. 131: 105-110.

Mejbaum-Katzenellenbogcn W., Mochnacka I., 1968. Kurs praktyczny z biochemii. PWN Wrocław, p. 323.

Morel G. M., 1974. Clonal Multiplication of Orchids in C. L. Withner The Orchids. New York-London, p. 169-222.

Now o sielski O., 1968. Metody oznaczania potrzeb nawożenia. PWRiL Warszawa p. 667.

R a o A. N., 1977. Tissue Culture in the Orchid Industry. [In:] J. Reinert and Y. P. S. Bajaj, Plant Cell, Tissue and Organ Culture. Berlin-IIeidelberg-New York, p. 45-69.

\section{WPEYW PODEOŻA NA ROZWOJ CYMBIDIUM W KULTURZE IN VITRO}

\section{Streszczenie}

Badano wpływ różnych podłoży na wzrost i rozwój 2 odmian storczyków Cymbidium we wczesnych stadiach rozwojowych w kulturze in vitro. Do podłoży: agarowego, kaszy jęczmiennej, płatków owsianych i perlitu dodawano płynną pożywkę PB w pelnym składzie i bez peptonu Peptobak-Bacutil. Po 4 miesiącach kultury zanalizowano rośliny morfologicznie i chemicznie.

Stwierdzono, że tradycyjne agarowe podłoże, wzbogacone w odpowiednią pożywkę, zapewnia kulturze Cymbidium dobre warunki edaficzne dla rozwoju roślin, jednak jego konsystencja, złe warunki powietrzne nie sprzyjają wrastaniu korzeni do podłoża. Kasza jęczmienna wzbogaca środowisko dodatkowo w makro- i mikroelementy, sprzyja wzrostowi pędów i korzeni Cymbidium i jest najlepszym podłożem wśród testowanych. Płatki owsiane jako podłoże bogate $w$ makro- i mikroelementy wpływają na silny wzrost pędów Cymbidium oraz na tworzenie się licznych korzeni. Jednak złe stosunki powietrzno-wodne tego podłoża hamują wzrost korzeni. Periit jest bardzo ubogim w składniki odżyweze podłożem, trudnym do 
wzbogacenia, jednakże stwarza doskonałe warunki powietrzne dla rozwoju korzeni Cymbidium.

Stwierdzono również, że zawartość podstawowych pierwiastków w roślinach byı̀a proporcjonalna do zawartości tych pierwiastków w podłożu. Obecność peptonu w pożywce PB powodowała zwiększenie ilości świeżej masy, u odmiany Cymbidium Vieux Rose del Park nawet dwukrotnie. 